\title{
Quinonoid constituents as contact sensitisers in Australian blackwood (Acacia melanoxylon RBR)*
}

\author{
B M HAUSEN ${ }^{1}$ AND H SCHMALLE 2 \\ From the Laboratory for Experimental Allergology, Department of Dermatology, University Hospital, \\ Hamburg, and the Institute of Mineralogy and Petrography, University of Hamburg, West Germany
}

\begin{abstract}
Australian blackwood (Acacia melanoxylon RBR) is a valuable commercial timber that since 1925 has been incriminated as being injurious to health. In addition to toxic effects numerous cases of allergic contact dermatitis and bronchial asthma have been observed in woodworkers. Several constituents have been identified in recent years, but none of them could be considered as aetiological factors. Sensitising experiments performed with blackwood heartwood extracts corroborated the described sensitising properties. Chemical studies showed the occurrence of two or possibly three quinones that produced positive skin responses in the sensitised guinea pigs. The main contact allergens were isolated and identified by $x$-ray analysis. The first, a yellow quinone, was identified as 2,6-dimethoxy-1,4-benzoquinone while the second, a red quinone, has the structure of 6-methoxy-2-methyl-3,5-dihydrobenzofurano-4,7-dion and was named acamelin. Whereas 2,6-dimethoxy-p-benzoquinone is already known from natural sources, acamelin is new and belongs to the rare group of naturally occurring furanoquinones. Though the obtained sensitising capacity of $A$ melanoxylon RBR in respect of its quinones is not high, it should be considered as a possible source of allergic contact dermatitis, especially as greater amounts of Australian blackwood may enter European countries in the near future.
\end{abstract}

Australian blackwood (Acacia melanoxylon RBR) belongs to the family of Leguminosae-Mimosaceae and is one of at least 100 different wood species of commercial value that are capable of inducing allergy of the cell-mediated type (delayed type of allergy, allergic contact dermatitis) in men handling it. ${ }^{1} A$ melanoxylon RBR is native to Western Australia. Owing to its dark brown colour and fine and decorative appearance it is used in Australia not only for high quality furniture, panelling, joinery, turnery, and shop and bank fittings, but also for bent work in coach- and boat-building, for handles, and even for parts of musical instruments. ${ }^{2}$

For decades Australian blackwood has also been cultivated in East and South Africa and considerable amounts are exported to Britain. As it is intended to

* Part VI of the series "The sensitising capacity of naturally occurring quinones." Part $\mathrm{V}$ is reference 25.

Received 16 June 1980

Accepted 17 September 1980 introduce this timber to other European countries in the near future, we have investigated this species for sensitising constituents.

\section{Contact dermatitis}

Cases of contact dermatitis as well as outbreaks of bronchial asthma after the handling and inhalation of fine wood dust and shavings have been described since 1925 . Mainly workers in joineries and motorboat factories have been affected, developing itching, weeping dermatitis and circumscribed skin lesions on the forearms, neck, and face. ${ }^{34}$ Nott $^{5}$ suffered from a papular rash on his hands and forearms after handling the wood at his home. Robertson $^{6}$ described 10 cases, one of which had bronchial asthma but nine had contact dermatitis. Though his patch tests remained negative, Robertson suggested that sensitisation had played a part. Further cases without detailed descriptions of the observations have been mentioned by Behl et al, ${ }^{\text {? }}$ Cleland, ${ }^{8}$ Hurst, ${ }^{9}$ and two anonymous authors. ${ }^{10} 11$ Recently three new cases of allergic contact derma105 
titis were reported by Burry. ${ }^{12} \mathrm{He}$ stated that Australian blackwood is specially mentioned in the Workmen's Compensation Act, 1965, of South Australia. This Act implies that any dermatitis occurring in a patient in contact with blackwood is considered to be the result of exposure to blackwood until proved otherwise.

In addition to Australian blackwood, some other related species of the genus Acacia may cause dermatitis and asthma-for instance, $A$ cyperophylla F MUELLER (Red mulga), ${ }^{813} A$ shirleyi MAIDEN (Lancewood), ${ }^{3}$ and $A$ harpophylla $\mathrm{F}$ MUELLER (Brigalow). ${ }^{14}$ Among these wood species Brigalow is the most notorious, causing what is known as "Brigalow itch."15

\section{Previous chemical investigations}

In addition to the observed skin irritant and sensitising properties of Acacia species there is evidence that several species are toxic to stock and man. ${ }^{9}$ At least 20 species, native to Australia or cultivated or growing wildly in New Zealand, have been examined for the occurrence of saponins. ${ }^{16}$ Large amounts of alkaloid-like substances such as $\beta$-phenyl ethylamine and tryptamine were isolated from most of them, including $A$ melanoxylon RBR.17 Phytochemical studies on the heartwood constituents of Australian and African species of Acacia have been performed by Tindale and Roux ${ }^{18-20}$ and others, ${ }^{21}$ yielding evidence for the wide distribution of flavonoids in this genus. From $A$ melanoxylon RBR higher amounts of (-)-melacacidin and (-)isomelacacidin were isolated. ${ }^{18}$

Although these constituents throw some light on the chemotaxonomic and phylogenetic aspects of Acacia species, none of the compounds detected so far can seriously be referred to as contact sensitisers.

\section{Material and methods}

To prove the sensitising capacity of heartwood extracts of $A$ melanoxylon $\mathrm{RBR}$ and to isolate their aetiologically active constituents, sensitising experiments were carried out in guinea pigs, and chemical studies were performed by column and thin-layer chromatography (TLC).

Different samples of $A$ melanoxylon RBR were kindly supplied by:

(1) Pieces of heartwood and sapwood and branches from (a) $8 \mathrm{~km} \mathrm{E}$ of Sandy Hill on the Bruxner highway, New South Wales; (b) $82 \mathrm{~km}$ ENE of Armidale on the Dorrigo road, NSW, $30^{\circ} 22^{\prime} \mathrm{S}$, $152^{\circ} 30^{\prime} \mathrm{E}$; and (c) Swamp Creek, $20 \mathrm{~km} \mathrm{NE}$ of Tenterfield, NSW (all by Dr Tindale).

(2) Pieces of heartwood from a timber merchant, Geelong, Victoria (Mr Lindemann).

(3) Pieces of heartwood from a timber merchant in Sidney (Dr Taylor).

(4) Pieces of heartwood grown in South Africa (Mr Gottwald).

Altogether $1600 \mathrm{~g}$ of wood samples were available and have been used for sensitising experiments, patch tests, and chemical investigations.

\section{OPEN EPICUTANEOUS SENSITISATION \\ PROCEDURE}

Ten female albino guinea pigs of the Pirbright white-strain were sensitised with a blackwood extract, made by extracting the heartwood shavings for 24 hours with pure ethanol at room temperature. The residue left after evaporation of the solvent at reduced pressure (water pump vacuum) and

Table 1 Results of sensitising experiments and challenges with chromatographically separated fractions and purified constituents of blackwood ethanol extracts

\begin{tabular}{|c|c|c|c|c|c|c|c|c|c|c|c|c|c|}
\hline \multirow{3}{*}{$\begin{array}{l}\text { No of } \\
\text { animals }\end{array}$} & \multirow{3}{*}{$\begin{array}{l}\text { Sensitised } \\
\text { with }\end{array}$} & \multirow{3}{*}{$\begin{array}{l}\text { Challenged } \\
\text { with }\end{array}$} & \multirow{3}{*}{$\begin{array}{l}\text { Concentration } \\
(\%)\end{array}$} & \multicolumn{10}{|c|}{ Challenge after } \\
\hline & & & & \multicolumn{5}{|c|}{24 hours } & \multicolumn{5}{|c|}{48 hours } \\
\hline & & & & $+t+$ & ++ & + & $(+)$ & $\emptyset$ & +++ & ++ & + & $(+)$ & $\emptyset$ \\
\hline \multirow[t]{2}{*}{10} & $\begin{array}{l}\text { Ethanol } \\
\text { extract }\end{array}$ & $\begin{array}{l}\text { Ethanol } \\
\text { extract }\end{array}$ & 10 & 2 & 2 & 5 & 1 & - & - & 3 & 4 & 2 & 1 \\
\hline & " & ", & 5 & - & 4 & 5 & 1 & - & - & 4 & 4 & 1 & 1 \\
\hline 10 & ", & ," & 1 & - & 2 & 4 & 2 & 2 & - & 2 & 2 & 2 & 4 \\
\hline 5 & $"$ & Quinone I & 1 & - & - & 4 & 1 & - & - & - & 3 & 2 & - \\
\hline 5 & $"$ & Quinone II & 1 & - & 2 & 2 & 1 & - & - & 2 & 2 & 1 & - \\
\hline 5 & $"$ & Fraction 3 & 1 & - & - & - & - & 5 & - & - & - & - & 5 \\
\hline 5 & " & Fraction 4 & 1 & - & - & - & - & 5 & - & - & - & 一 & 5 \\
\hline
\end{tabular}

Evaluation of the intensity of skin reactions:

0 No reaction.

(+) Slight erythema (visible and distinguishable from a negative reaction).

+ Distinct erythema restricted to the test area.

+ Distinct confluent erythema and infiltration, slight swelling, but restricted to the test area.

+++ Intense erythema, infiltration and exudation with swelling and spreading over the test area. 
low temperature $\left(39^{\circ} \mathrm{C}\right)$ was dissolved in acetone to a $10 \%$ solution. Each day $0.05 \mathrm{ml}$ of this crude extract was applied to a $2 \mathrm{~cm}^{2}$ test area on the clipped and shaved flank of the animals. Nine days after beginning this treatment a slight erythema developed that increased steadily until it reached a maximum of a +++- reaction on day 17 . The treatment was then stopped.

Two weeks after the sensitisation procedure, challenge was carried out by epicutaneous application of $0.05 \mathrm{ml}$ of different concentrations of the crude ethanol extract on the opposite flank of the guinea pigs. Readings of the test area after 24 and 48 hours indicated that all animals had been sensitised (table 1).

\section{CHEMICAL EXPERIMENTS}

Separation of the ethanol extract in different solvent systems by analytical TLC showed several quinonoid compounds in the heartwood. This was shown by spraying the thin-layer plates with Craven solution. ${ }^{22}$ The Craven test, a highly specific reagent for benzoquinones and naphthoquinones, requires the presence of a labile hydrogen or halogen atom adjacent to the carbonyl group of the quinoid ring.* Extracts containing such quinones show blue or green spots after separation on thin-layer plates.

Subsequent extraction of the wood shavings with cold ethyl acetate and later with hot ethyl acetate $\left(60^{\circ} \mathrm{C}\right)$ yielded further quantities of the detected quinones.

The crude separation of all the heartwood extracts on silica gel columns was followed by further purification steps on preparative TLC-plates using at first a one-dimensional method with chloroformmethanol $(100+2)$ (solvent system I). Four fractions were obtained, of which two contained the enriched quinones. In later experiments separation of the quinone-enriched fractions in two dimensions was preferred, using solvent system I in one direction and benzene-acetone $(100+5)$ in the other.

The purified quinones and the remaining fractions were used to challenge the sensitised guinea pigs. The positive test responses made clear that the quinones had to be considered the responsible aetiological agents (table 1). Chemical examination of the sapwood and bark were followed up in the same manner. Spraying of the separated bark extract with Craven solution gave no specific colour reaction, whereas the sapwood showed low amounts of the yellow quinone.

\footnotetext{
*Equal amounts of absolute ethanol and ammonia (25\%) are mixed with three to five drops of ethyl cyanoacetate.
}

\section{Results}

The results obtained in the guinea pig experiments with the crude extracts of the heartwood showed a medium sensitising capacity for Australian blackwood. In the material supplied from the Royal Botanic Gardens and National Herbarium of Sydney (Dr Tindale) traces of a third quinone were detectable by the Craven test in addition to the two main quinones. Wood samples supplied later from other sources ( $\mathrm{Dr}$ Taylor, $\mathrm{Mr}$ Gottwald) contained only the two main contact allergens.

After final purification two quinones were isolated:

I A yellow quinone; $8.6 \mathrm{mg}$, recrystallised from ether-ethyl acetate, $\mathrm{mp}$ : dec $250-252^{\circ} \mathrm{C}$.

II A red quinone; $15.8 \mathrm{mg}$, recrystallised from acetone, $\mathrm{mp}: 175-176^{\circ} \mathrm{C}$ (uncorr).

Both quinones were the only constituents to give positive skin responses in the sensitised guinea pigs. During elicitation the red quinone showed a slightly stronger and longer lasting reaction than the yellow quinone (table 1).

Elucidation of the structures was carried out by $x$-ray analysis. The yellow quinone was identified as 2,6-dimethoxy-1,4-benzoquinone (fig 1). The red quinone could be identified as a new benzofuranoquinone that we named acamelin (fig 1). Detailed information on the procedures for elucidation of their structures was given in two preliminary short communications. ${ }^{23} 24$

\section{Discussion}

Australian blackwood may affect health in several ways: in addition to the toxic effects allergic dermatitis and bronchial asthma may occur in people handling the wood and inhaling the wood shavings. The toxic properties are probably due to the alkaloid-like constituents occurring in varying concentrations in this species. The constituents responsible for allergic contact dermatitis in woodworkers are two quinones found in the heartwood. The causative agents of the asthmatic reactions remain unidentified.<smiles>COC1=CC(=O)C=C(OC)C1=O</smiles>

2,6 - dimethoxy-1,4benzoquinone

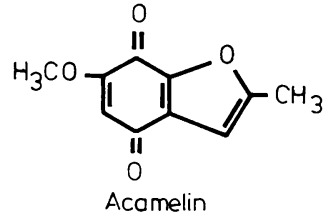

6- methoxy-2-methyl-3,5-dihydro benzo (b) furano-4,7-dion
Fig 1 Quinonoid contact allergens of Acacia melanoxylon RBR (Australian blackwood). 
Table 2 Comparison of sensitising capacity of 2,6-dimethoxy-1,4-benzoquinone with related naturally occurring quinones obtained by guinea pig muximisation sensitisation experiments ${ }^{25}$

\begin{tabular}{|c|c|c|c|}
\hline Quinone & Occurrence & Name & $\begin{array}{l}\text { Obtained } \\
\text { sensitising } \\
\text { capacity }\end{array}$ \\
\hline $\begin{array}{l}\text { Thymoquinone } \\
\text { Obtusaquinone } \\
\text { Macassar quinone* } \\
\text { 2,6-dimethoxy-1,4-benzoquinone } \\
\text { Toluquinone } \\
\text { Lapachol } \\
\text { Rapanone } \\
\text { Quinone } \mathrm{Q}_{4} \\
\text { 2,5-dimethoxy-1,4-benzoquinone }\end{array}$ & $\begin{array}{l}\text { Calocedrus decurrens (TORR) FLORIN } \\
\text { Dalbergia retusa HEMSLEY } \\
\text { Diospyros celebica } \text { BAKH } \\
\text { Acacia melanoxylon RBR } \\
\text { Brachinus crepitans } \text { L } \\
\text { Tectona grandis } \text { L } \\
\text { Ardisia macrocarpa WALLICH } \\
\text { Diospyros melanoxylon GUILL \& PERR } \\
\text { Diospyros melanoxylon GUILL \& PERR }\end{array}$ & $\begin{array}{l}\text { Incense cedar } \\
\text { Cocobolo } \\
\text { Macassar ebony } \\
\text { Australian blackwood } \\
\text { Arthropodes } \\
\text { Teakwood } \\
\text { Coromandel ebony } \\
\text { Coromandel ebony }\end{array}$ & $\begin{array}{l}\text { Strong } \\
\text { Medium }\end{array}$ \\
\hline
\end{tabular}

* Occurs in the wood as the precursor macassar II.

The sensitising potency of the wood and its quinonoid constituents was shown in guinea pig sensitisation experiments. Though the wood samples were obtained from different sources (Australia, Africa), it is obvious that these two quinones are the main contact sensitisers. It must be remembered, however, that blackwood trees from different localities may yield varying amounts of these constituents and, under certain circumstances, may contain a third quinone. Whether this quinone plays a part in blackwood sensitivity is undetermined.

The simple yellow 2,6-dimethoxy-1,4-benzoquinone has previously been discovered and isolated from 25 different wood and plant species and was recently detected in an additional 21 species. ${ }^{25}$ Its sensitising capacity has been proved in guinea pig sensitisation experiments and was compared with that of 10 related naturally occurring quinones (table 2). The results showed a slight sensitising power that indicates that in single cases of plant and wood dermatitis 2,6-dimethoxy-p-benzoquinone should be recognised as a possible sensitiser.

Acamelin, the red quinonoid allergen of Australian blackwood is a 6-methoxy-2-methyl-3,5-dihydrobenzo-(b)furano-4,7-dion. Naturally occurring furanoquinones are rare. Four similar but naphtho-<smiles></smiles><smiles>[R]C1Cc2c(oc3c2C(=O)c2ccccc2C3=O)O1</smiles>

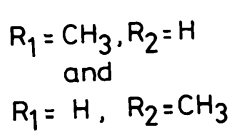<smiles>[R]C=C(C)C[R]</smiles>

Fig 2 Naturally occurring furanoquinones from peroba wood (Paratecoma peroba KUHLM). furanoquinones were isolated and identified in 1968 from Peroba wood Paratecoma peroba KUHLM (family: Bignoniaceae) ${ }^{26}$ (fig 2). Although these quinones have not been examined with respect to their sensitising properties, it is known that Peroba wood is also responsible for allergic contact dermatitis. ${ }^{27}$ The present findings show once more that quinonoid constituents of plants and woods are of considerable and ever increasing dermatological interest. Numerous benzo- and naphtho- quinones have been isolated from natural sources in the past two decades and their sensitising capacity has been confirmed in animal experiments. ${ }^{28} 29$ Furthermore, recent research has shown that cross-reactivities exist between different but chemically related benzo- and naphtho- quinones. ${ }^{28} 29$ This knowledge is important in view of the possible recurrence of allergic contact dermatitis, which may develop in individuals who are sensitive to distinct plant or wood quinones. In those patients who acquired their quinone-sensitivity occupationally or through a hobby, recurrent dermatitis may develop after contact with other quinone-containing plants, wood species, or natural products, such as wooden shoes (clogs), knife-handles, recorders, and wooden jewellery by accident or changing a working place. ${ }^{30}$

We thank Deutsche Forschungsgemeinschaft, Bonn, for financial support and the following people for supplying us with samples of Australian blackwood: Dr D M Tindale, Royal Botanic Garden and National Herbarium, Sydney; Dr W C Taylor, Department of Organic Chemistry, University of Sydney; and Mr E Lindemann, Geelong, Victoria, Australia. We are furthermore indebted to the reference librarian of the medical library of the University of Sydney for copies of difficultly accessible publications and $\mathrm{Mr} \mathrm{H}$ Gottwald, scientific director at the Institute of Wood Biology, Hamburg, for the supply and botanical identification of blackwood samples. 


\section{References}

${ }^{1}$ Hausen BM.Woods injurious to human health. On the toxic, irritant, sensitizing, asthmatogenic and carcinogenic properties of commercial timbers. Berlin, New York: W de Gruyter, 1981.

${ }^{2}$ Farmer RH. Handbook of hardwoods. 2nd ed. London: HMSO, $1972: 43$.

${ }^{3}$ Cleland JB. Plants, including fungi, poisonous or otherwise injurious to man in Australia. Med J Aust 1925;12: 443-51.

${ }^{4}$ Pulleine RH. Sensitiveness to proteins of wood. Med J Aust 1925;12:25.

${ }^{5}$ Nott H. Diseases communicated by plants. Med J Aust 1925;12:464.

${ }^{6}$ Robertson DG. An investigation of certain health aspects in persons engaged in the wood-working industries. Melbourne: Commonwealth of Australia, Department of Health, 1927:1-36. (Ser Publ No 4.)

' Behl PN, Captain RM, Bedi BMS, Gupta S. Skin-irritant and sensitizing plants found in India. New Delhi: PN Behl, 1966:2.

${ }^{8}$ Cleland JB. Plants, including fungi, poisonous or otherwise injurious to man in Australia. Med J Aust 1931;18: 775-8.

${ }^{9}$ Hurst E. The poisonous plants of New South Wales. Sydney: Poisonous Plants Committee, New South Wales, 1942:147-8.

${ }^{10}$ Anonymous. Les maladies professionelles dans l'industrie du bois. Annales d'Hygiene publique 1935;13:139-66.

${ }^{11}$ Anonymous. Dermatitis from plants. $S$ Afr Med J 1968; 42:569.

${ }^{12}$ Burry JN. The value of patch testing: a review of 363 cases of allergic contact dermatitis. Med J Aust 1969: 1226-9.

${ }^{13}$ Webb LJ. Guide to the medicinal and poisonous plants of Queensland. Melbourne: Commonwealth Scientific and Industrial Research Organisation, 1948:106. (Bulletin No 232.)

14 Maiden JH. Plants which produce inflammation or itritation of the skin. Agricultural Gazette of New South Wales $1921 ; 32: 206$.

15 Maiden JH. Notes on Acacia. Journal and Proceedings of the Royal Society of New South Wales 1919;53:171239.

${ }^{16}$ Simes JJH, Tracey JG, Webb LJ, Dunstan WJ. An
Australian phytochemical survey. Melbourne: Commonwealth Scientific and Industrial Research Organisation, 1959:10. (Bulletin No 281.)

${ }^{17}$ White EP. Alkaloids of the Leguminosae. New Zealand Journal of Science and Technology 1944;25B:137, 157.

18 Tindale MD, Roux DG. An extended phytochemical survey of the Australian species of Acacia. Phytochemistry 1969;8:1713-27.

${ }^{19}$ Tindale MD, Roux DG. An extended phytochemical survey of the Australian species of Acacia: chemotaxonomic and phylogenetic aspects. Phytochemistry 1974; 13:829-39.

20 Tindale MD, Roux DG. Phytochemical studies on the heartwoods and barks of African and Australian species of Acacia. Boissiera 1975;24:299-305.

${ }^{21}$ Clark-Lewis JW, Dainis J. Flavan derivatives. Australian Journal of Chemistry 1967;20:2191-8.

${ }^{22}$ Craven $R$. A sensitıve colour reaction for certain quinones. $J$ Chem Soc 1931:1605.

${ }^{23}$ Schmalle H, Jarchow O, Hausen BM. 2,6-dimethoxy-1,4benzoquinone, a new contact allergen in commercial woods. Naturwiss $1977 ; 64: 534$.

${ }^{24}$ Schmalle H, Hausen BM. Acamelin, a new sensitizing furano-quinone from Acacia melanoxylon RBR. Tetrahedron Letters 1980;21:149-51.

${ }^{25}$ Hausen BM. The sensitizing capacity of naturally occurring quinones. V 2,6-dimethoxy-1,4-benzoquinone: occurrence and significance as a contact allergen. Contact Dermatitis 1978;4:204-13.

${ }^{26}$ Sandermann W, Simatupang $\mathrm{MH}$, Wendeborn W. Neue Chinone aus dem Kernholz von Paratecoma peroba. Naturwissenschaphen 1968 ;55:38-9.

${ }^{27}$ de Jong JC, Lenstra JB, Vermeer DJH. Eczema due to the wood of Peroba do Campos. Acta Derm Venereol $1951 ; 31: 108-10$.

${ }^{28}$ Schulz KH, Garbe I, Hausen BM, Simatupang MH. The sensitizing capacity of naturally occurring quinones. Experimental studies in guinea pigs. I Naphthoquinones and related compounds. Arch Dermatol Res 1977;258: 41-52.

${ }^{29}$ Schulz KH, Garbe I, Hausen BM, Simatupang MH. The sensitizing capacity of naturally occurring quinones. II Benzoquinones. Arch Dermatol Res 1979;264:275-85.

${ }^{30}$ Hausen BM. Belufsbedingte Kontaktdermatitiden durch Pflanzen und Hölzer. Arbeitsmedizin, Sozialmedizin, Präventivmedizin 1978;13:161-6. 